Journal American Society of Mining and Reclamation, 2018 Vol.7, No.3

\title{
EUCALYPT PLANTATIONS FOR MULTIPLE PURPOSES IN THE HUNTER VALLEY, AUSTRALIA ${ }^{1}$
}

\author{
Ashley A. Webb ${ }^{2}$, Georgina L. Kelly, and Nicholas L. Cameron
}

\begin{abstract}
Coal mining is central to economic development in the Hunter Valley, New South Wales, Australia with $>100$ million tonnes of black coal produced annually. Rehabilitation is mandatory following the mining process and $\sim 20,000$ ha of land is undergoing rehabilitation in the Upper Hunter Valley (UHV). The mean annual rainfall of $<700 \mathrm{~mm}$ is significantly lower than typical for growing hardwood plantations. The traditional post-mining land use has been extensive grazing of beef cattle; however, in line with local government strategy replicated plantation forest trials were established in the late 1990s and early 2000s on buffer sites and reshaped overburden in the UHV to investigate the potential commercial viability of growing plantation forests as an alternative post-mining industry - for wood products and carbon credits. Following on from earlier establishment trials, the focus of this paper is the performance of the $\sim 15$ years old dryland plantations, with the objective of quantifying the benefits of an early non-commercial thinning and pruning regime. Seven hardwood eucalypts were trialed in this project: Corymbia maculata (Spotted gum), Eucalyptus camaldulensis, E. argophloia, E. molluccana, E. sideroxylon, E. camaldulensis x grandis and E. camaldulensis $\mathrm{x}$ globulus. The best all round performer to date has been Spotted gum. While it has grown well on buffer sites, most stands have performed as well or better on the reshaped overburden. Thinning at age 10-12 years has not led to an increase in overall stand volume; however, at the majority of sites it has increased the mean diameter and height of retained trees. Initial assessments indicate that thinning is likely to produce stands of better form resulting in the growth of higher value timber products. We developed an economic model to compare returns from grazing with expected returns from Spotted gum forestry and agroforestry using growth and yield projections. Net present values and internal rates of return indicate that forestry and agroforestry deliver comparable commercial returns (from carbon and wood products) to grazing but with a different investment and risk profile.
\end{abstract}

Additional Key Words: Mine site rehabilitation, Spotted gum, forestry, agroforestry, grazing, carbon sequestration, wood products.

\footnotetext{
${ }^{1}$ Oral paper presented at the 2018 National Meeting of the American Society of Mining and Reclamation, St. Louis, MO: The Gateway to Land Reclamation, June 3 - 7, 2018. Published by ASMR; 1305 Weathervane Dr., Champaign, IL 61821.

${ }^{2}$ Dr Ashley A. Webb, formerly Principal Research Scientist, Plant Systems, New South Wales Department of Primary Industries, Tamworth Agricultural Institute, 4 Marsden Park Rd, Calala NSW 2340, Australia; Current details: Manager Water Monitoring, Water NSW, PO Box 1251, Tamworth NSW 2340, Australia; Dr Georgina L. Kelly, Director Environmental Protection Science, NSW Office of Environment and Heritage, 480 Weeroona Rd, Lidcombe NSW 2141, Australia; and Nicholas (Nick) L. Cameron, Forest Resource Analyst, NSW Department of Primary Industries, 10 Valentine St, Parramatta NSW 2124, Australia.
}

DOI: http://dx.doi.org/10.21000/JASMR18030045 


\section{$\underline{\text { Introduction }}$}

Coal mining is central to economic development in the Hunter Valley, New South Wales, Australia with >100 million tonnes of black coal produced annually from the Hunter Valley Coal Chain (Singh et al., 2012). Rehabilitation is mandatory following the mining process and $\sim 20,000$ ha is undergoing rehabilitation in the UHV. There are 17 mines in the UHV all of which undertake regular rehabilitation to provide temporary or final cover of land disturbed by mining (Department of Planning and Environment, 2017). In general, the steps involved in mine site rehabilitation include (Bell, 2001; Lamb et al., 2015):

- Modifying the topography by re-contouring of the site to minimize steep areas and to ensure that slopes are stable;

- Re-spreading topsoil that has been stockpiled (although this is not always available);

- Improving soil physical properties usually by ripping or ploughing;

- Establishing vegetation cover either by direct seeding or the planting of seedlings; and

- Applying fertilizers, biosolids or other soil amendments (Kelly, 2008).

The typical land use following rehabilitation in the UHV coalfields is agistment of cattle for grazing on re-established pastures. However, in response to a request from the community, local government and industry, a series of plantation forest trials were established in the late 1990s and early 2000s to investigate the potential commercial viability of growing plantation forests as an alternative land use. An earlier project trialed the establishment of a range of hardwood tree species using different soil amendments during the first 5 years on both overburden rehabilitation and buffer land sites (Kelly, 2008). One of the main conclusions from that trial was that an initial application of biosolids provided adequate nutrition on overburden sites leading to better growth of plantations than repeated applications of inorganic fertilizers (Kelly, 2008).

Following on from the establishment trial, the focus of this research was the ongoing management and performance of the dryland forest plantations with the objective of quantifying the benefits of an early non-commercial thinning and pruning regime. Identified potential benefits include increases in biomass production, tree and stand growth and carbon sequestration. The original trial sites of Kelly (2008) are included, together with other sites to provide a Hunter Valley-wide perspective. This makes the results applicable and pertinent to the majority of the Valley's mines. This phase of the research was conducted between 2011 and 2016. 
This research aimed to:

- Gather a Hunter Valley-wide database on most of the oldest tree plantations;

- Apply thinning and pruning regimes to assess the benefit of early application in dryland plantations;

- Provide full rotation projections (from year 15 data) on performance of species, land type and the species/land type interaction;

- Quantify the commercial costs and returns from carbon and timber from C. maculata (Spotted gum) plantations; and

- Compare investment in grazing agistment with plantation forestry and agroforestry options.

Growth and silvicultural data are scarcely available for dryland eucalypt plantations in NSW, which underlines the importance and significance of this research.

\section{Methods}

\section{$\underline{\text { Study Sites }}$}

The Hunter Valley is a large coastal catchment of approximately 22,000 $\mathrm{km}^{2}$ located in central eastern New South Wales, Australia. It is bounded to the north by the Liverpool Range, Mount Royal Range and Barrington Tops, to the south by dissected sandstone plateaux of the Southern Mountains and to the west by a low saddle of the Central Goulburn Valley (Galloway, 1963; Erskine and Fityus, 1998). The research trials were conducted at six sites in the UHV where hardwood plantations were established in the late 1990s and early 2000s (Fig. 1). Mean annual rainfall at Singleton for the period 2002-2017 was $659 \mathrm{~mm}$ with a median of $666 \mathrm{~mm}$ and a range of 424-899 mm.

The UHV Coalfields overlie the geological Sydney Basin, where the main economic coal seams form part of the Greta Coal Measures and the Wittingham Coal Measures, both of Permian age (Roberts et al., 1991). Five of the study sites are located on and adjacent to open cut mines producing thermal and semi-soft coking coal, while the sixth site is located adjacent to a coal-fired power station. The study sites are on three different land types: 'overburden,' 'buffer' and 'river' sites. Overburden sites comprise rehabilitated mine overburden; buffer sites are located on pastoral land adjacent to mine sites; while river sites are located on floodplains adjacent to mines. 


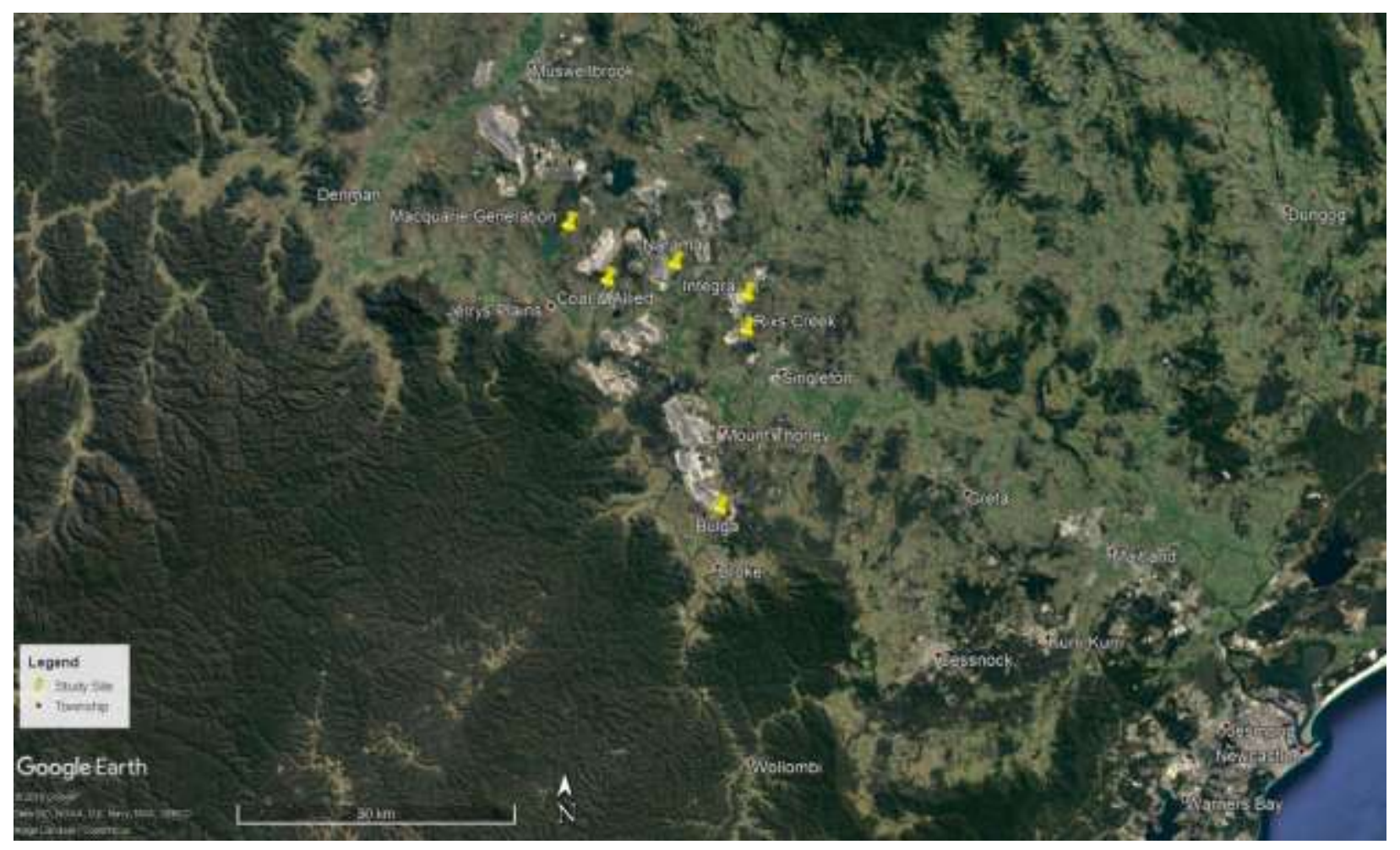

Figure 1. Location of study sites in the Upper Hunter Valley.

In total, 8,990 trees were planted in the trial plots used in this research. Plots typically comprise 40 trees and the initial stocking of the plantations was $\sim 1,000$ stems/ha. Plots included in this project had survival rates greater than $75 \%$ and were not confounded by previous establishment technique (i.e., establishment technique was a non-significant variable) or by soil physical or chemical characteristics (Kelly, 2008). At locations where thinning treatments were applied, a control (un-thinned) plot was retained for each plot thinned. Between one and four hardwood eucalypt species were planted at each site with a number of plots thinned in 2011 or retained as controls. A summary of the characteristics of the study sites is provided in Table 1. Further details can be found in Kelly (2008) and Webb et al. (2017). 
Table 1. Study site characteristics

\begin{tabular}{|c|c|c|c|c|c|}
\hline Site name ${ }^{\mathrm{a}}$ & Co-ordinates & $\begin{array}{l}\text { Land } \\
\text { type(s) }\end{array}$ & Species trialed $^{\mathrm{b}}$ & $\begin{array}{l}\text { Year } \\
\text { est. }\end{array}$ & Treatments \\
\hline Bulga & $\begin{array}{l}32^{\circ} 42^{\prime} 16^{\prime \prime S} \\
151^{\circ} 6^{\prime} 0^{\prime \prime} \mathrm{E}\end{array}$ & $\begin{array}{l}\text { Buffer } \\
\text { Overburden }\end{array}$ & $\begin{array}{l}\text { C. maculata } \\
\text { E. camaldulensis } \\
\text { E. camaldulensis } \mathrm{x} \text { grandis }\end{array}$ & $\begin{array}{l}1999- \\
2000\end{array}$ & Control \\
\hline $\begin{array}{l}\text { Coal \& } \\
\text { Allied }\end{array}$ & $\begin{array}{l}32^{\circ} 29^{\prime} 3 " \mathrm{~S} \\
150^{\circ} 58^{\prime} 16^{\prime \prime} \mathrm{E}\end{array}$ & $\begin{array}{l}\text { Buffer } \\
\text { Overburden } \\
\text { River }\end{array}$ & $\begin{array}{l}\text { C. maculata } \\
\text { E. camaldulensis } x \text { grandis } \\
\text { E. camaldulensis } \mathrm{x} \\
\text { globulus }\end{array}$ & 2001 & $\begin{array}{l}\text { Thinned \& } \\
\text { Control }\end{array}$ \\
\hline Integra & $\begin{array}{l}32^{\circ} 29^{\prime} 54^{\prime \prime S} \\
151^{\circ} 72^{\prime \prime} \mathrm{E}\end{array}$ & $\begin{array}{l}\text { Overburden } \\
\text { River }\end{array}$ & $\begin{array}{l}\text { C. maculata } \\
\text { E. camaldulensis } \mathrm{x} \text { grandis }\end{array}$ & 2001 & $\begin{array}{l}\text { Thinned \& } \\
\text { Control }\end{array}$ \\
\hline $\begin{array}{l}\text { Macquarie } \\
\text { Generation }\end{array}$ & $\begin{array}{l}32^{\circ} 25^{\prime} 51^{\prime \prime} \mathrm{S} \\
150^{\circ} 55^{\prime} 35^{\prime \prime} \mathrm{E}\end{array}$ & Buffer & $\begin{array}{l}\text { C. maculata } \\
\text { E. argophloia } \\
\text { E. molluccana } \\
\text { E. sideroxylon }\end{array}$ & 2000 & $\begin{array}{l}\text { Thinned \& } \\
\text { Control }\end{array}$ \\
\hline Narama & $\begin{array}{l}32^{\circ} 28^{\prime} 6 " \mathrm{~S} \\
151^{\circ} 2^{\prime} 55^{\prime \prime} \mathrm{E}\end{array}$ & Overburden & $\begin{array}{l}\text { C. maculata } \\
\text { E. camaldulensis } \mathrm{x} \text { grandis }\end{array}$ & 2004 & Control \\
\hline $\begin{array}{l}\text { Rixs } \\
\text { Creek }\end{array}$ & $\begin{array}{l}32^{\circ} 31^{\prime} 57^{\prime \prime S} \\
151^{\circ} 72^{\prime \prime} \mathrm{E}\end{array}$ & Overburden & C. maculata & 2004 & Control \\
\hline
\end{tabular}

${ }^{a}$ Site name at time of trial establishment

${ }^{b}$ Tree species were provided by Forests NSW and sourced from the same nursery

Tree Measurements. Each plot included in this phase of the research was measured, where the site was still accessible, in 2011, 2012, 2014, and 2016. Previous measurements were part of the former project (Kelly, 2008). At each field measurement visit the following was recorded:

- Survival;

- Diameter at breast height (DBH) over bark, of each stem $>3 \mathrm{~cm}$, measured using a diameter tape; and

- Height of each dominant stem, measured using an optical vertex.

Thinning and Pruning Treatments. Non-commercial thinning and pruning of the designated "Thinned" plots were conducted over a period of 2.5 months from October to December of 2011 using a protocol derived from Bird (2000) and Andrews et al. (2004). Approximately 1350 trees were manually felled (Fig. 2) by an experienced and accredited tree faller across the thinned plots 
at the Macquarie Generation, Coal \& Allied and Integra sites to a stocking of $\sim 500$ stems/ha. The thinning aimed to remove $50 \%$ of the trees, preferably leaving no more than 2-3 trees together along rows. The objective was to retain the most vigorous (preferably dominant and co-dominant) and least deformed trees, or those which could be successfully form-pruned in the lower $3 \mathrm{~m}$. Approximately 1,800 trees were pruned to a height of $3 \mathrm{~m}$ in the thinned plots. Regrowth and any coppicing that was apparent in the thinned plots were removed in 2012 and the stumps treated with glyphosate.

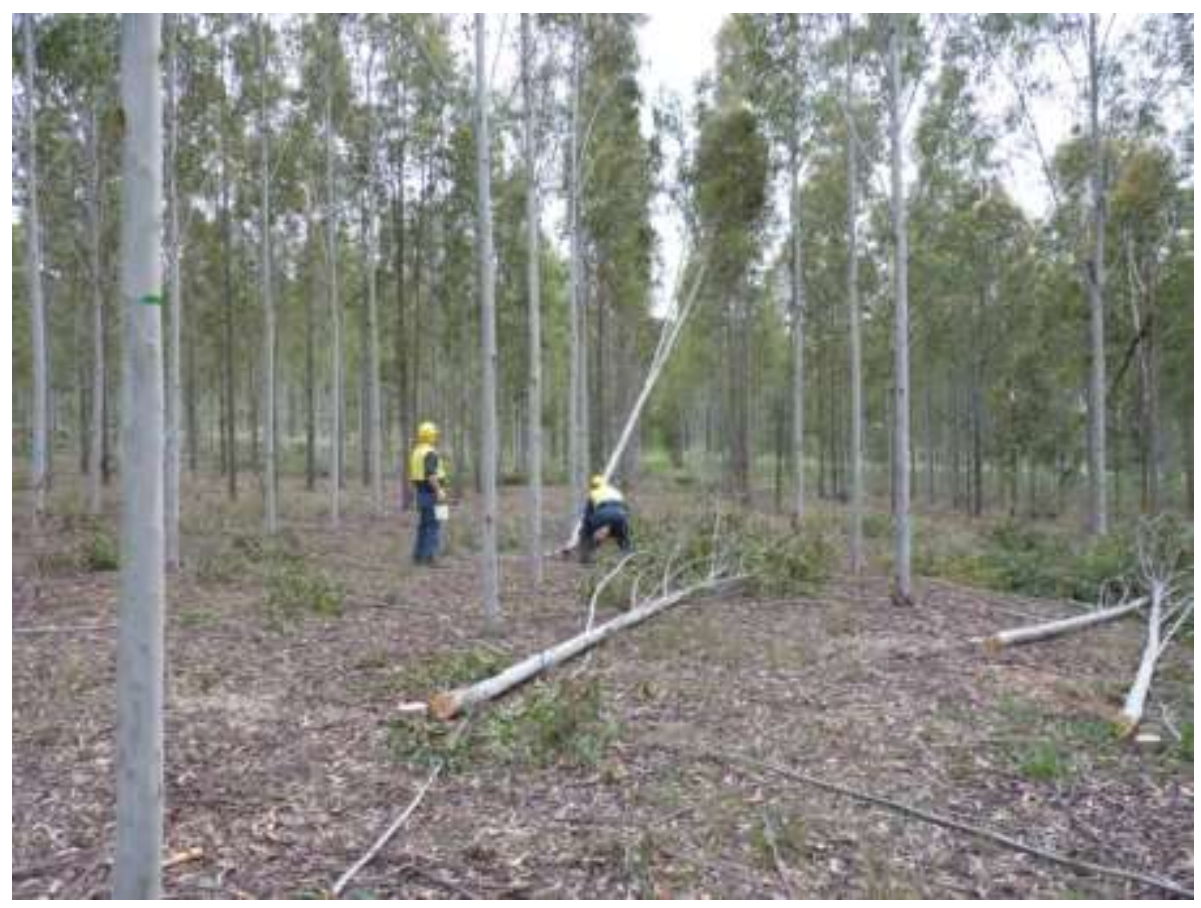

Figure 2. Manual thinning of E. camaldulensis x grandis trees, Integra 2011.

Data Analysis and Growth Projections. For each plot the following calculations were made for each measurement period $(2011,2012,2014$, and 2016):

- Stocking (stems/ha);

- Basal Area $\left(\mathrm{m}^{2} / \mathrm{ha}\right)$;

- Stand Volume ( $\left.\mathrm{m}^{3} / \mathrm{ha}\right)$;

- Dominant Height (m) - mean height of the largest 100 stems/ha; and

- Dominant DBH (cm) - mean DBH of the largest $100 \mathrm{stems} / \mathrm{ha}$.

These calculations allowed analysis of trends in plantation growth over time, and comparison with other published results from dryland eucalypt plantations of a similar age (e.g., Barton and Parekh, 2005; Walsh et al., 2008). For the C. maculata plantations, commercial-in-confidence 
yield tables were obtained from the Forestry Corporation of NSW and compared with the growth data measured in the trial plots. Based on these yield tables from other locations, projected growth curves were produced for both thinned and control plantations of this species through to their final harvest age. Such projections were not attempted for the other species planted due to their generally lower performance or, in the case of E. camaldulensis x grandis trees, due to an absence of any comparable data on mature plantations of this clonal hybrid.

Commercial Viability Assessment. An economic model was developed to enable cashflow analysis of existing and alternative rehabilitated land use options over 35 years (for a single forestry crop, i.e., over one rotation) and 70 years (for multiple forestry crops, i.e., over two rotations):

- Grazing of beef cattle, as per existing lease arrangements;

- Forestry plantations for timber, carbon sequestration and some limited grazing; and

- Agroforestry, including pasture and trees planted in wide spaced rows for grazing, timber, and carbon sequestration.

Grazing of beef cattle is the most common land use on rehabilitated mine sites and on mine buffer lands in the UHV. It is common practice for mining companies to agist rehabilitated mine land to graziers under multi-year commercial leases. Lease fees are typically 'area based' (e.g. dollars per hectare per year). Lease areas are usually a single fenced paddock designed for continuous grazing. Paddock sizes typically range between 40 and 100 ha.

Under the forestry modelled option C. maculata was established as an even-aged hardwood plantation at $1,000 \mathrm{stem} / \mathrm{ha}$, non-commercially thinned to $500 \mathrm{stems} / \mathrm{ha}$, and subject to a final harvest at age 35. Under the Agroforestry modelled option C. maculata was established as an even-aged hardwood plantation at 200 stems/ha, non-commercially thinned to $100 \mathrm{stems} / \mathrm{ha}$, and pruned with a final harvest at age 35 . Grazing stock were introduced at year six at which time the trees were assumed to be sufficiently well established to withstand grazing pressure.

For costing purposes, the plantations were assumed to be established in commercial blocks of 50 ha. The principal income from the plantations was sawlogs and poles domestically processed and sold as solid timber products and low-grade timber sold as pulpwood. To realize their carbon sequestration benefits the plantations were modelled in accordance with a plantation forestry methodology that has been approved by the Australian government under its carbon farming 
initiative (Department of the Environment and Energy, 2017). Full details of the methods used, including economic assumptions, can be found in Webb et al. (2017).

\section{$\underline{\text { Results and Discussion }}$}

\section{$\underline{\text { Tree Measurements }}$}

A range of techniques and soil amendments were used in the establishment of these trials. At establishment and in early growth, biosolids and standards rates of NPK fertilizer were the most effective amendments, and were equivalent in effectiveness (Kelly, 2008). However, by age of 10 years, there was no significant difference in growth between any of the treatments across the range of trial sites. Therefore, amendment type was not an impediment to the plots being included in this superimposed thinning trial. Two species were planted across a number of sites in the valley:

- C. maculata; and

- E. camaldulensis x grandis.

Given that there are differences in the planting dates, as well as some of the measurement dates, it was necessary to present the calculated data against plantation age (rather than year of measurement). In addition, the following cross-valley results are presented by species and also by land cover type (buffer, overburden, river).

Corymbia maculata at Buffer sites. Corymbia maculata (Spotted gum) trees were planted on buffer sites at three locations: Coal \& Allied, Macquarie Generation, and Bulga. The standing volume of the plantations is greatest at Coal \& Allied, followed by Macquarie Generation, and Bulga (Fig. 3). The standing volumes measured by Walsh et al. (2008) at age 10 in southern NSW were in the range of $41-66 \mathrm{~m}^{3} / \mathrm{ha}$. The Coal \& Allied Control (un-thinned) plantations are at the upper end of this range, while the Macquarie Generation plantations fall within it. The Bulga plantations were performing comparatively poorly when last measured. In terms of mean Dominant DBH (largest 100 stems/ha), however, there is little difference between the sites (Fig. 4) indicating that the differences in volume are a combination of survival/stocking and height. Assessment of the dominant height data (Fig. 5) shows that indeed the dominant trees are tallest

at Coal \& Allied followed by Macquarie Generation, and Bulga. The southern NSW data of Walsh et al. (2008) on dryland sites exhibited a dominant height range of 13.9 to $16.0 \mathrm{~m}$ at age 10 . The Coal \& Allied, Buffer plantations fit within this range but the Macquarie Generation and Bulga plantations were somewhat shorter. 
Journal American Society of Mining and Reclamation, 2018 Vol.7, No.3

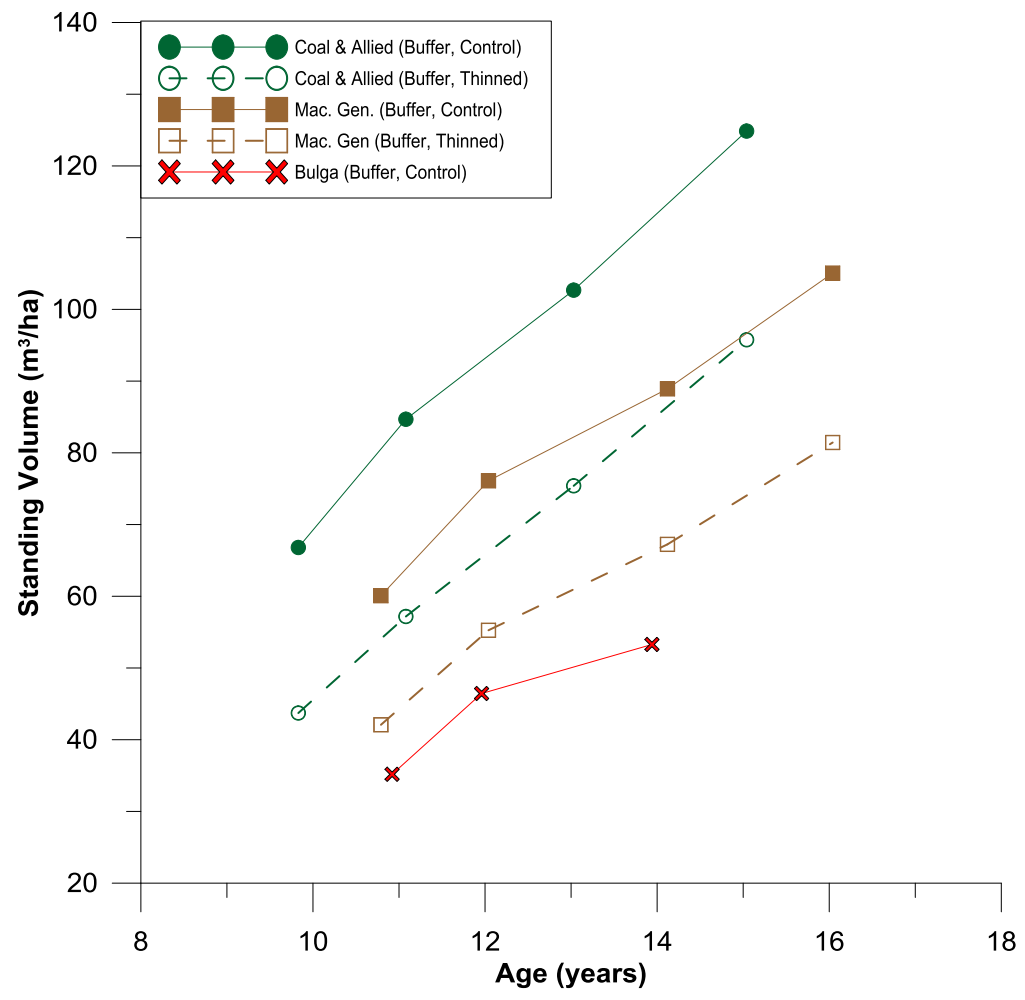

Figure 3. Standing volume of C. maculata plantations at buffer sites.

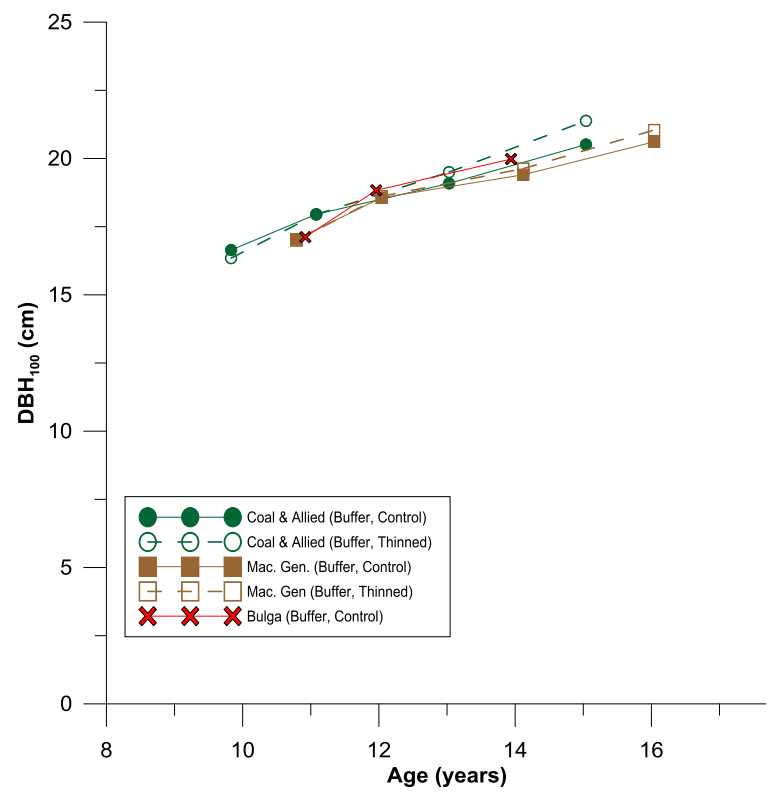

Figure 4. Dominant DBH, top 100 trees/ha $\left(\mathrm{DBH}_{100}\right)$ of $C$. maculata plantations at buffer sites.

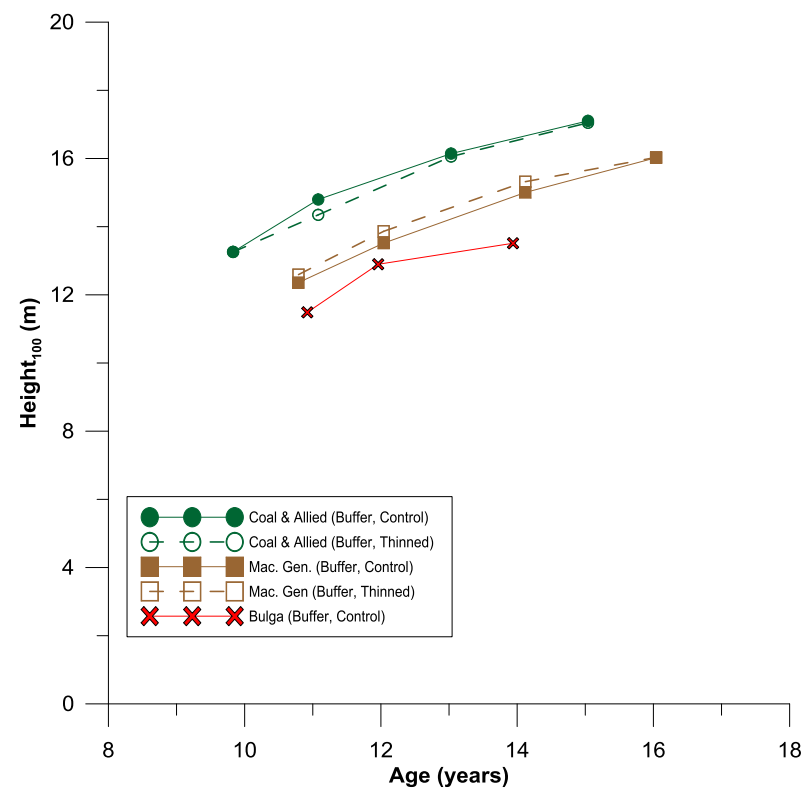

Figure 5. Dominant Height, top 100 trees/ha (Height ${ }_{100}$ ) of $C$. maculata plantations at buffer sites. 
Corymbia maculata at Overburden sites. Corymbia maculata plantations were established at five of the UHV sites on rehabilitated overburden. As with the buffer sites, the greatest standing volumes on overburden are present at Coal \& Allied, with the next highest standing volumes found at the Integra site (Fig. 6). An interesting finding is that the volumes are higher at Coal \& Allied on overburden than on the buffer sites. Lower standing volumes, but similar across all three sites, were exhibited at the overburden sites at Rixs Creek, Narama, and Bulga. The dominant DBH of C. maculata overburden plantations is greatest at Integra but similar at the other sites (Fig. 7), while the dominant height is also greatest at the Integra overburden and lowest at the Bulga and Narama sites (Fig. 8). While the Integra and Rixs Creek overburden sites are adjacent it is clear that the standing volumes are higher at the Integra site. We believe one of the main reasons for this is due to the different dates of establishment. While the Integra overburden site was planted in 2001, the Rixs Creek and Narama overburden sites were not planted until 2004. The latter was an autumn planting that coincided with an extended drought. Hand watering was required in the first 12 months and this resulted in slower establishment at Rixs Creek and Narama (Kelly, 2008).

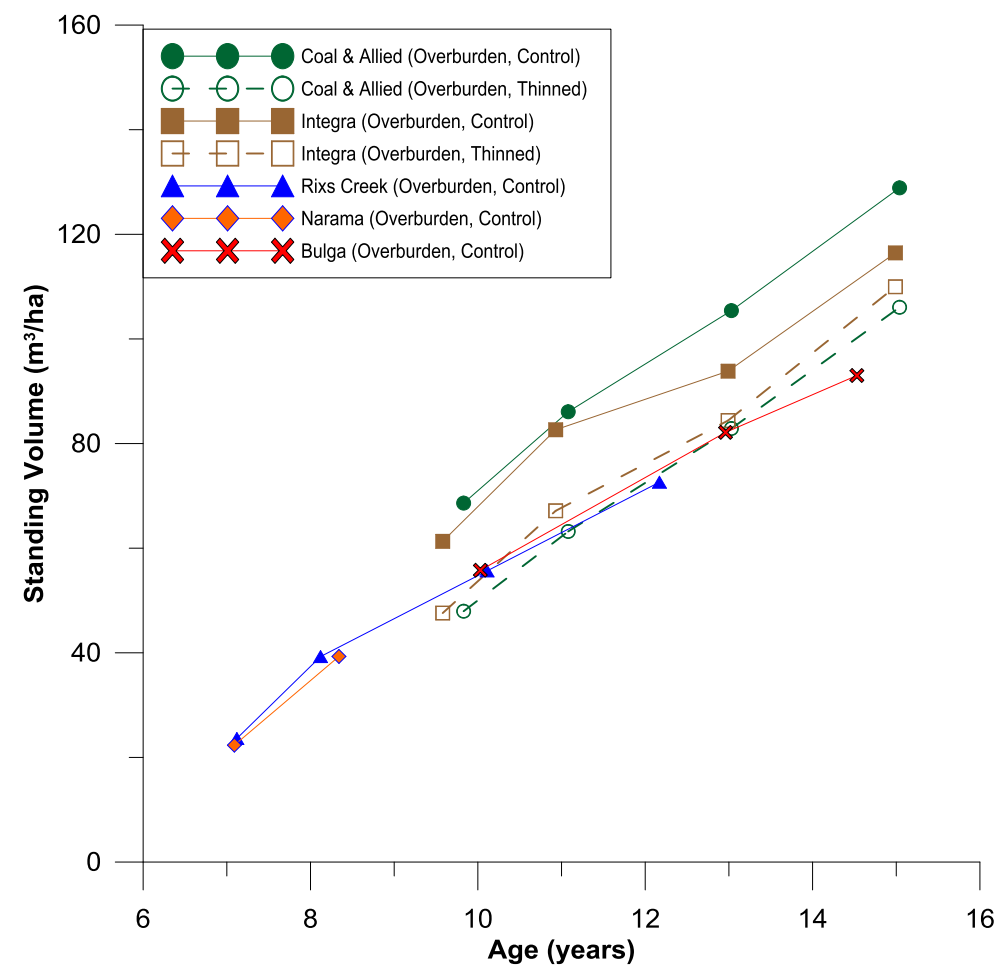

Figure 6. Standing volume of C. maculata plantations at overburden sites. 


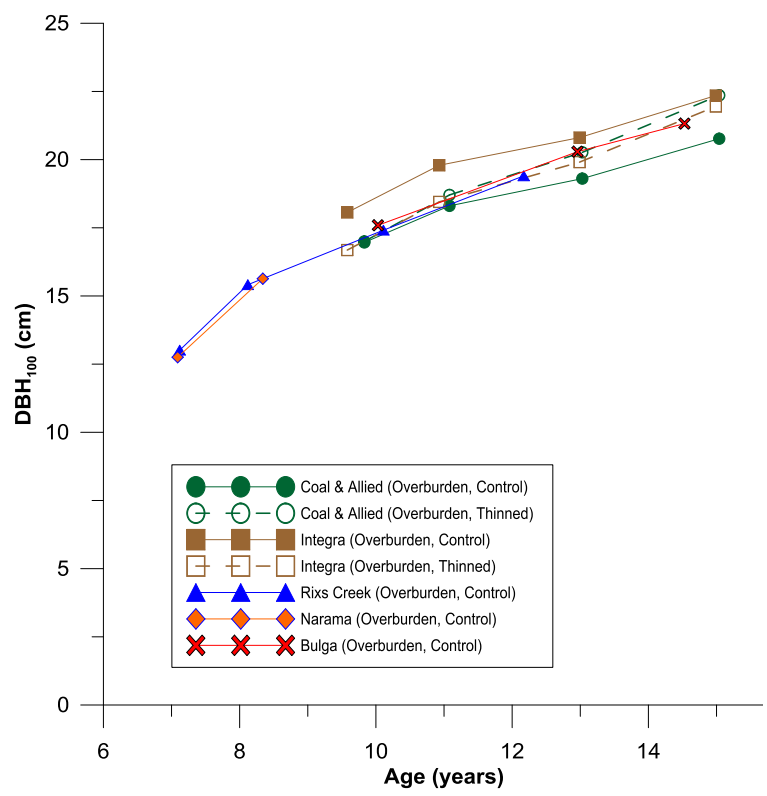

Figure 7. Dominant DBH, top 100 trees/ha $\left(\mathrm{DBH}_{100}\right)$ of $C$. maculata plantations at overburden sites.

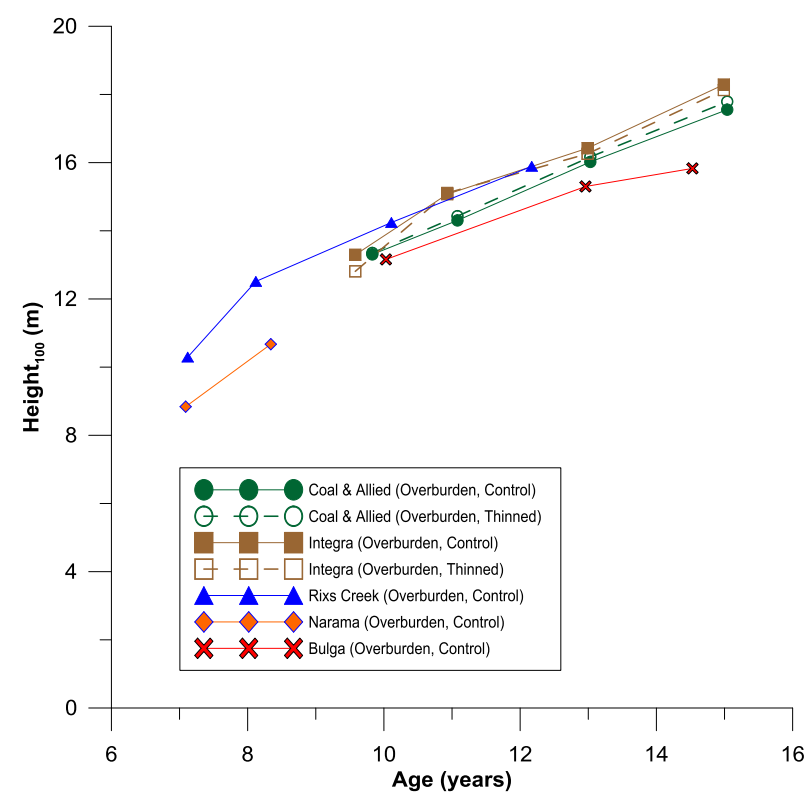

Figure 8. Dominant Height, top 100 trees/ha (Height 100$)$ of $C$. maculata plantations at overburden sites.

Eucalyptus camaldulensis x grandis at Buffer sites. The hybrid eucalypt, E. camaldulensis $\mathrm{x}$ grandis, was planted on buffer land at only two of the study sites. It has not performed as well as the C. maculata and standing volume is similar at the Coal \& Allied and Bulga sites, if slightly greater at the un-thinned Coal \& Allied site (Fig. 9). The mean dominant DBH was greater at the Bulga buffer site (Fig. 10), while the mean dominant height was slightly greater at the Coal \& Allied site (Fig. 11). The overall greater standing volume at the Coal \& Allied buffer site is attributed to a greater survival rate and stocking of $\sim 860$ stems/ha (un-thinned) compared to $\sim 550$ stems/ha at Bulga when last measured.

Eucalyptus camaldulensis $\mathrm{x}$ grandis at Overburden sites. The hybrid eucalypt was planted at four overburden sites with highly variable results. The trees are performing well at the Integra overburden site where standing volumes are more than double those measured at the Coal \& Allied, Bulga, and Narama overburden sites (Fig. 12). The Integra overburden hybrids have a substantially greater mean dominant DBH (Fig. 13) and mean dominant height (Fig. 14) than at the other sites. Further investigation of the causative factors contributing to the better performance at the Integra Overburden sites is required to explain these results. 


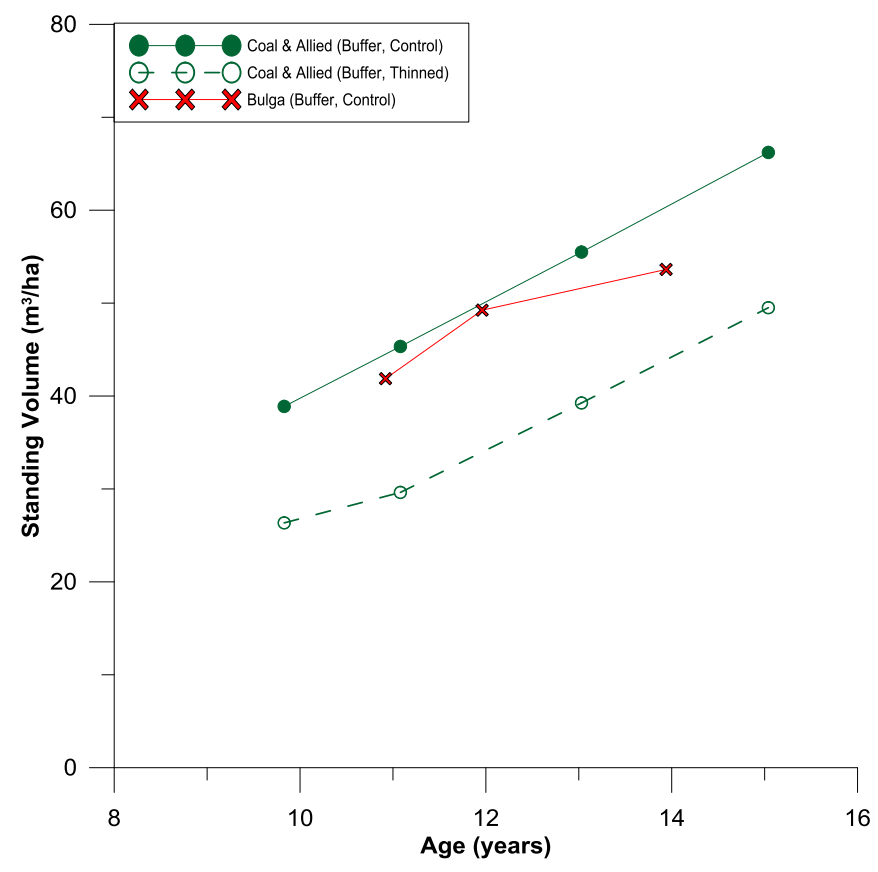

Figure 9. Standing volume of E. camaldulensis x grandis plantations at buffer sites.

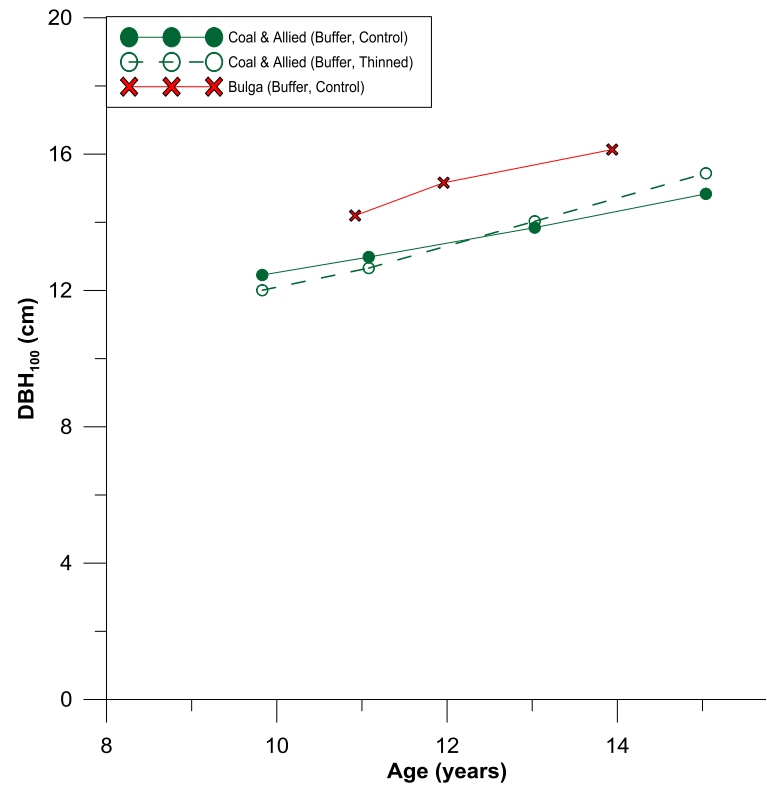

Figure 10. Dominant DBH, top 100 trees/ha $\left(\mathrm{DBH}_{100}\right)$ of E. camaldulensis $\mathrm{X}$ grandis plantations at buffer sites.

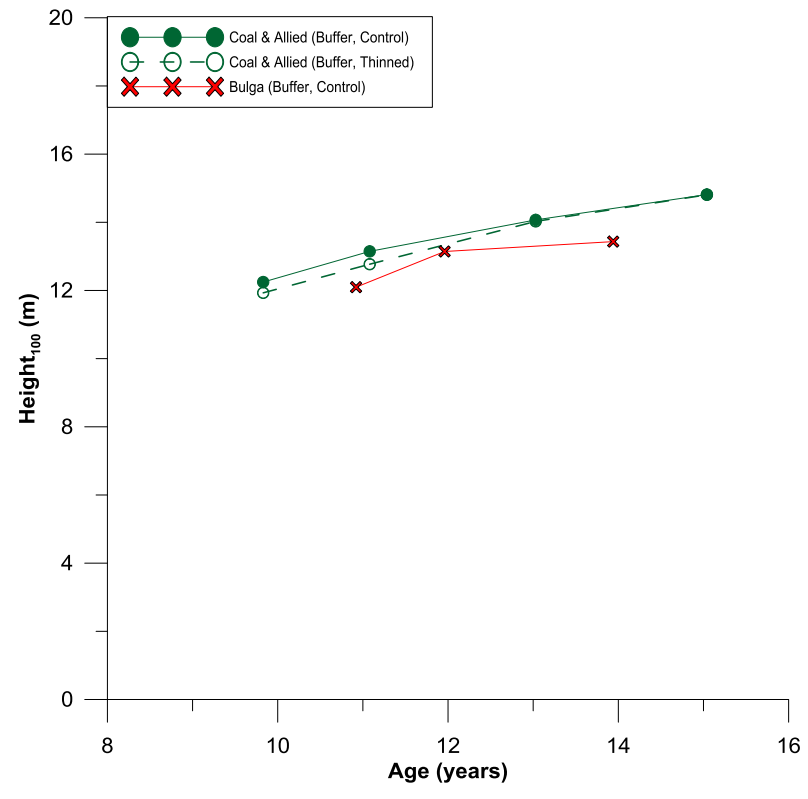

Figure 11. Dominant Height, top 100 trees/ha (Height 100 ) of $E$. camaldulensis $\mathrm{x}$ grandis plantations at buffer sites. 


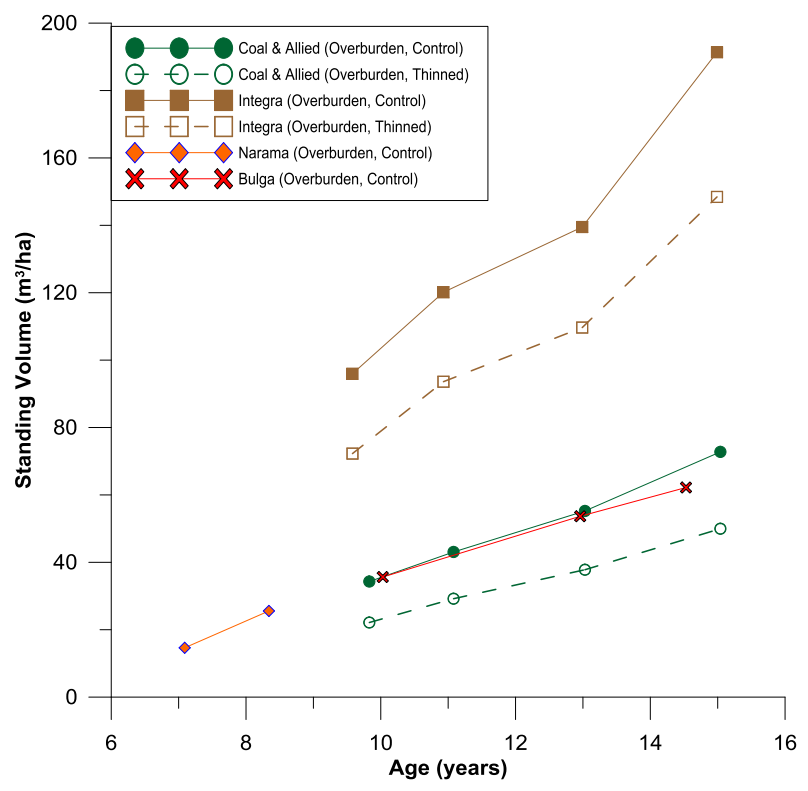

Figure 12. Standing volume of E. camaldulensis x grandis plantations at overburden sites.

Eucalyptus camaldulensis $x$ grandis at River sites. The hybrid eucalypts were planted at only two river sites: Integra and Coal \& Allied. Results are similar to the overburden sites in that the hybrids are performing well at Integra but not so at the Coal \& Allied river site. Standing volumes are up to 5 times greater at the Integra river site compared with Coal \& Allied (Fig. 15). The mean dominant DBH (Fig. 16) and mean dominant height (Fig. 17) are also substantially greater at the Integra river site when compared with the Coal \& Allied river site.

Other Species. Based on our trial measurements to date, none of the other species are recommended for use in commercial plantations in the study area. The E. camaldulensis (River red gum) plantations performed poorly on both the buffer and overburden, with the trees having a smaller diameter and being shorter than the other species (Fig. 18). The majority of trees of this species were of poor form, suggesting that the seedlings planted may have been sourced from poor stock. An alternative explanation is that as a riparian tree species E. camaldulensis shows a preference for higher available soil moisture and streamside locations (Webb et al., 1999; Webb and Erskine, 2003), as opposed to the drier ridgetops typically associated with rehabilitated overburden in the study area. 

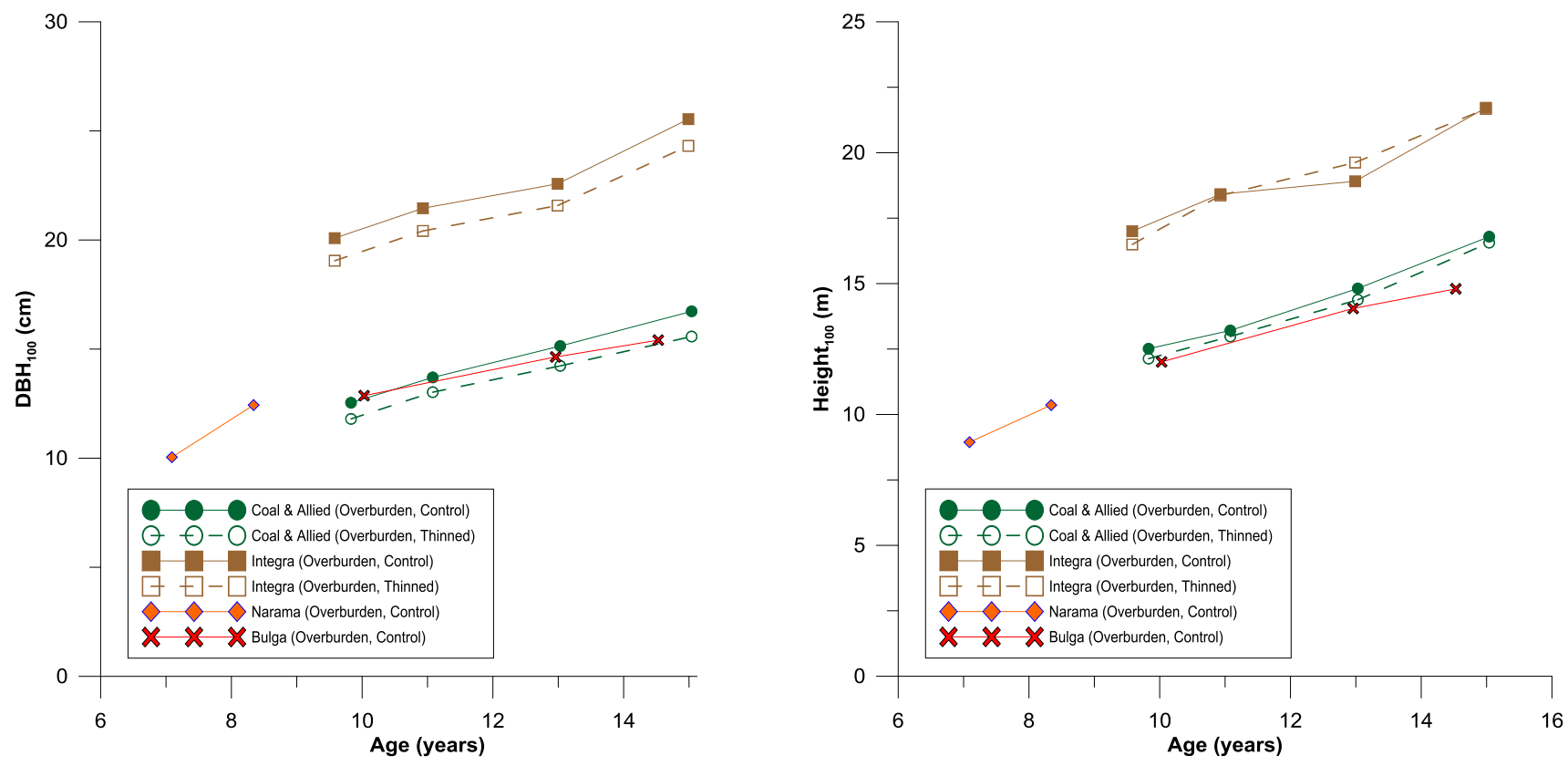

Figure 13. Dominant DBH, top 100 trees/ha $\left(\mathrm{DBH}_{100}\right)$ of E. camaldulensis $\mathrm{x}$ grandis plantations at overburden sites.

Figure 14. Dominant Height, top 100 trees/ha (Height ${ }_{100}$ ) of E. camaldulensis $\mathrm{x}$ grandis plantations at overburden sites.

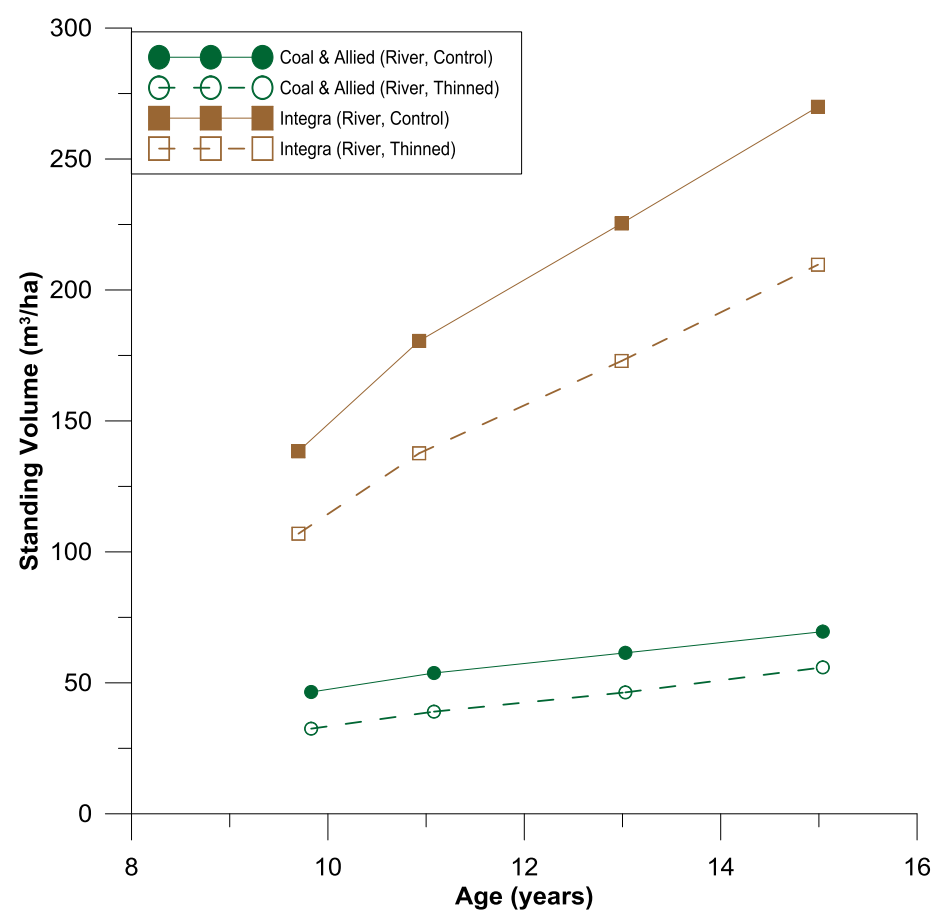

Figure 15. Standing volume of E. camaldulensis x grandis plantations at river sites. 


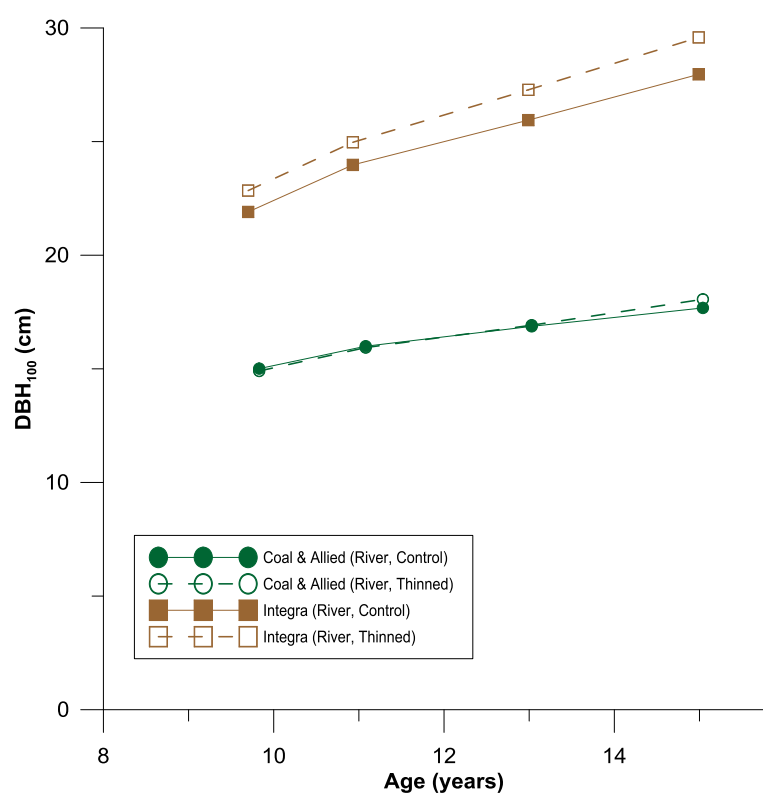

Figure 16. Dominant DBH, top 100 trees/ha $\left(\mathrm{DBH}_{100}\right)$ of E. camaldulensis $\mathrm{x}$ grandis plantations at river sites.

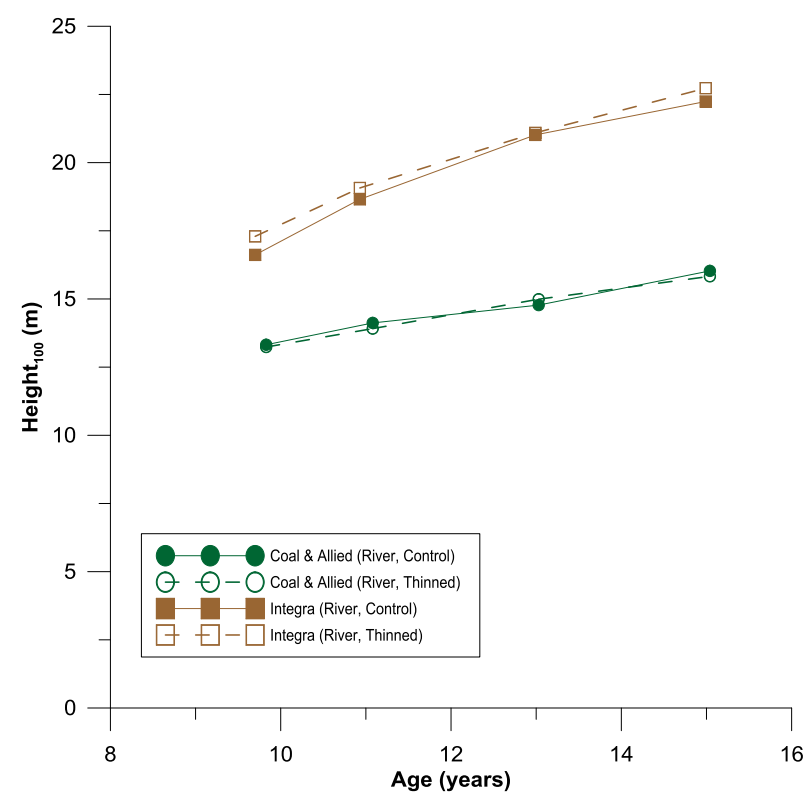

Figure 17. Dominant Height, top 100 trees/ha (Height 100$)$ of $E$. camaldulensis $\mathrm{x}$ grandis plantations at river sites.

Eucalyptus argophloia (Queensland white gum), E. molluccana (Grey box), and E. sideroxylon (Red ironbark) were only planted at the one site, Macquarie Generation, and were outperformed by the C. maculata plantations (Fig. 19). The final species trialed, E. camaldulensis x globulus, was planted at only one site, the river block at Coal \& Allied. While it performed well initially the plantation suffered from herbivorous insect attack between 2014 and 2016, which resulted in mortality and reduced stocking rates.

Effects of Thinning and Pruning. While in general thinning and pruning has not yet led to an increase in overall stand volume, at the majority of sites it has resulted in an increase in the mean dominant DBH and mean dominant Height of trees. Initial assessments indicate that thinning is likely to result in stands of better form, directing growth to the trees that have the greatest potential to yield high value timber products. Further measurements over the life of the plantations are recommended, however, before definitive conclusions can be drawn about the longer-term benefits of thinning and pruning. 


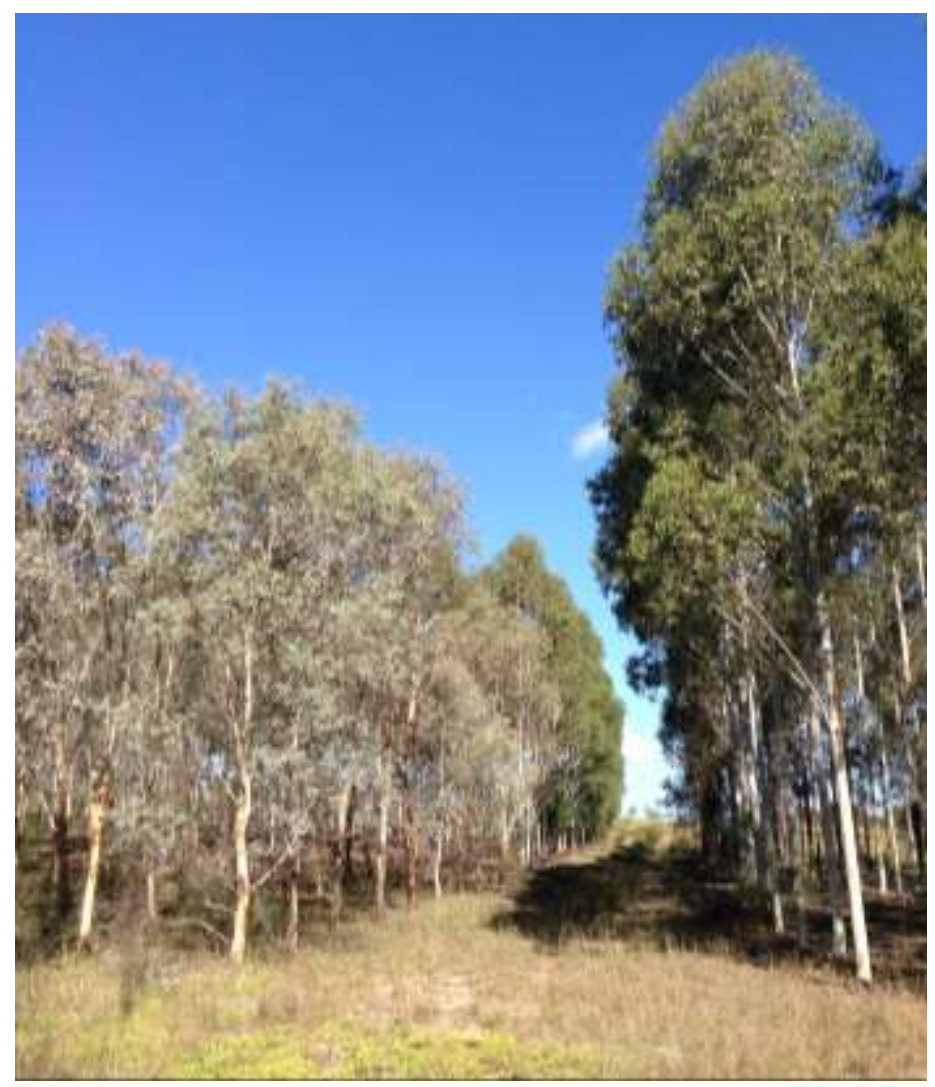

Figure 18. Eucalyptus camaldulensis (left) and E. camaldulensis $\mathrm{x}$ grandis (right) trees on the Bulga overburden, May 2014.

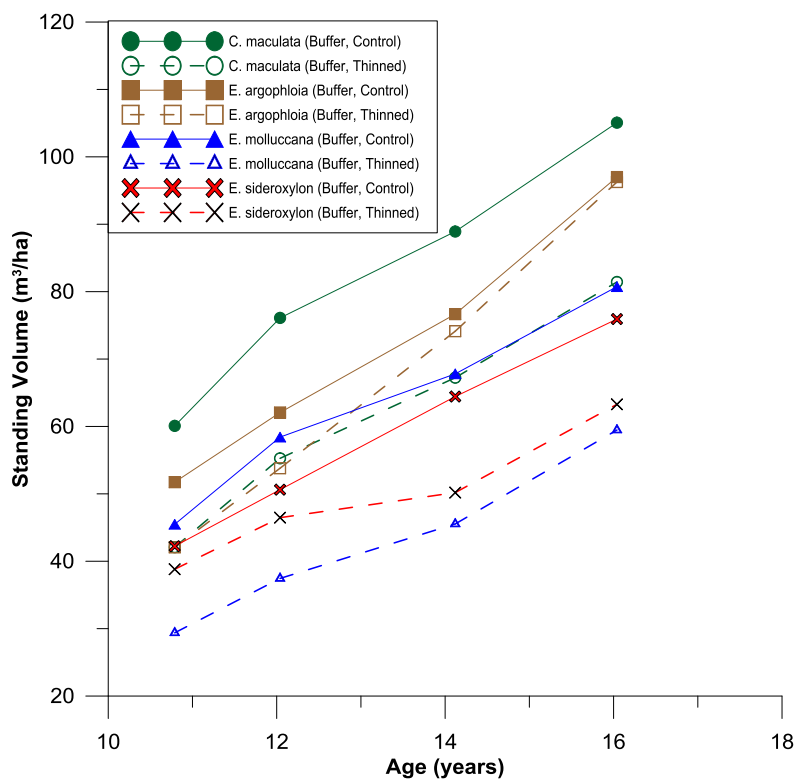

Figure 19. Standing volume of the Macquarie Generation buffer plantations by species and thinning treatment. 
Growth Projections. Growth projections were made for the one species that is recommended for future commercial planting at the UHV sites - C. maculata. Growth of the existing trial stands was compared with existing growth curves from a range of site qualities, provided by the Forestry Corporation of NSW. Those that most closely matched the data obtained from this trial were then used to produce projected growth curves for control and thinned standing volumes (Fig. 20). Full details, along with projected curves for mean dominant DBH and mean dominant height can be found in Webb et al. (2017).

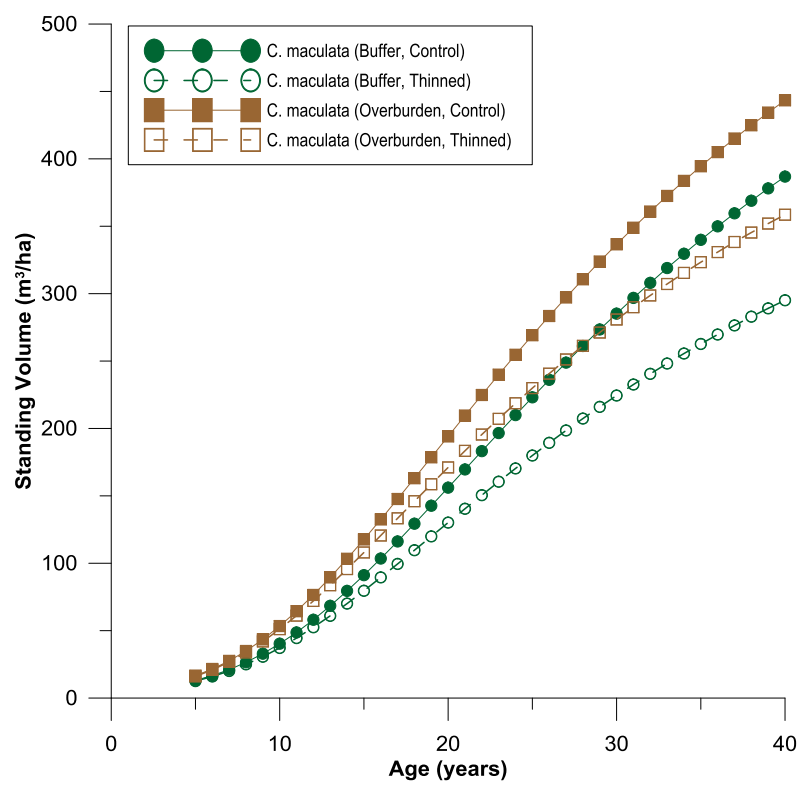

Figure 20. Projected standing volume growth curves for C. maculata (Spotted gum) plantations by land cover type and thinning treatment.

It should be noted that while these growth projections are the best available for these dryland plantations, they are a simulation only. Periodic future measurements are recommended to validate these curves and the economic analyses that rely upon them.

\section{Commercial Viability of Spotted Gum Plantations}

Assessment of the commercial viability of grazing, forestry and agroforestry land use options was based on cashflow analysis over a 35-year period for a single site/crop and over 70 years for multiple sites/rotations (Fig. 21). Of the three-land use options forestry had the highest long-term revenue stream if two rotations are considered. If the forestry and/or agroforestry options are limited to a single rotation (one age class) then the cashflow generated is irregular, though this is partially mitigated by revenue generated by carbon sequestration credits. Returns from continuous grazing were found to be sensitive to upfront fencing costs and agistment rates. Fence costs (per 
hectare) rise as paddock size reduces and vice versa. The agroforestry option offers a mix of lower risk grazing with higher risk forestry. By blending the two land uses the forestry risk is mitigated without losing all of the revenue flow benefits that are associated with an established (multi-aged) forestry estate.

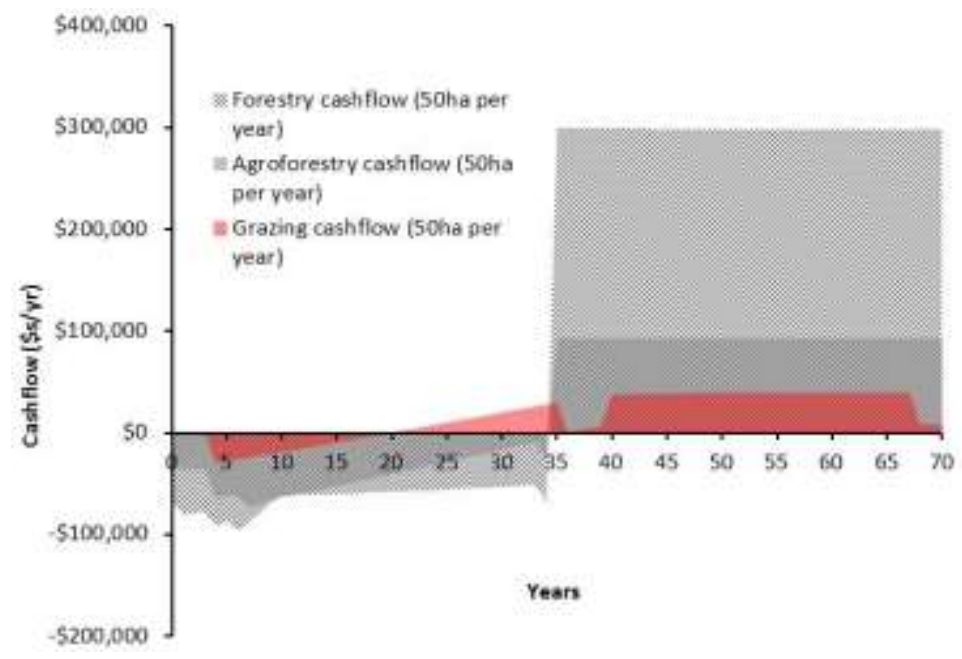

Figure 21. Forestry, grazing, and agroforestry cashflows for a 50-ha annual planting program continued for 35 years (1750 ha total) with replanting after final harvest.

With a commitment to a regular annual planting program the forestry/agroforestry options generate a much greater revenue stream over the longer term and produce a future resource upon which a new industry can be built. With over 800 ha of mined land rehabilitated annually we suggest there is a good case for diversification of land use through new investment in forestry and agroforestry.

\section{Conclusions}

Of the species trialed in this research, the best all round performer to date has been C. maculata. While it has grown well on buffer sites, most stands of $C$. maculata have performed as well or better on the overburden. While in general thinning has not led to an increase in overall stand volume, at the majority of sites it has resulted in an increase in the mean dominant DBH and mean dominant height of trees. Further measurements over the life of the plantations are recommended before statistically robust conclusions can be drawn about the longer-term benefits of thinning and pruning.

The trial plots of E. camaldulensis $\mathrm{x}$ grandis have to date yielded mixed results with the majority of buffer plantings not performing as well as the $C$. maculata. Due to these variable 
results and in the absence of long-term data from these or other sites, use of this hybrid species as a commercial option cannot be recommended at this time. Other species that were trialed are also not recommended for future use for various reasons. The E. camaldulensis stands grew poorly and this is attributed to the then available seedstock and/or that the species is not suitable to dry ridgetop locations. The E. camaldulensis x globulus river plantations at Coal \& Allied have grown well but suffered from severe herbivorous insect attack between 2014 and 2016. The other species, E. argophloia, E. molluccana, and E. sideroxylon, while exhibiting very good early growth, have been outperformed by the $C$. maculata stands over the longer term.

Spotted gum (C. maculata) was therefore considered to be the most commercially viable species for growing in the UHV coalfields due to its growth performance and its marketable wood

properties. Of the three land use options modelled, forestry had the highest long-term revenue stream but also the highest risk profile. However, if the coal mines commit to an annual planting program on rehabilitated overburden and buffer lands, the forestry/agroforestry options generate substantial cashflow and produce a valuable resource upon which a new industry may be built.

\section{Acknowledgements}

This research project would not have been possible without the co-investment and support of the Australian Coal Association Research Program (ACARP - Project C20015) and the various Hunter Valley-based companies that hosted the trials including Bulga Coal (Glencore), Coal \& Allied Hunter Valley Operations (Rio Tinto, now Yancoal), Integra Coal (Vale), Narama Coal (Ravensworth), Rixs Creek (Bloomfield Group), and Macquarie Generation (AGL Macquarie). The authors especially wish to thank the Industry Monitors, Bill Baxter (Coal \& Allied) and John Hindmarsh (Rixs Creek) for their support, advice, and guidance during this project, and Keith Smith and Nicole Youngman from ACARP for their administrative support. In-kind support of the NSW Department of Primary Industries is much appreciated.

Rebecca Coburn and Jagrutee Parekh dedicated an enormous amount of time to this project in its early years and we are extremely grateful for their efforts in establishing the trial plots, for field measurements, and data management. Dr Huiquan Bi was contracted to undertake growth projections of the $C$. maculata plantations to enable prediction of future standing timber volumes. David Bell and Brian Fischer from the Forestry Corporation of NSW provided the bulk of the tree measurements over the years, while Graeme Sonter and Tim Parkes from the Forestry Corporation 
supplied plantation costing and yield data. The in-kind support of the Forestry Corporation in the early years (prior to this project), when Dr Kelly was their employee, is duly acknowledged. During the latter years of the project, valuable assistance with field measurements was provided by Phil Hirst, Lloyd Finlay, and Clarence Mercer, who also collated the datasets for analysis. The authors thank two anonymous journal referees for constructively reviewing a draft of the manuscript.

\section{$\underline{\text { Literature Cited }}$}

Andrews, S., D. Carr, and H. Ward. 2004. A Manual for Planted Farm Forestry for the Northern Inland of New South Wales. Greening Australia New South Wales Inc.

Barton, C. and J. Parekh. 2005. Establishment of species demonstration trials in the 500-700 mm rainfall zone of New South Wales. Technical Paper No. 72, Forest Resources Research, NSW Department of Primary Industries, Sydney.

Bell, L. C. 2001. Establishment of ecosystems after mining - Australian experience across diverse biogeographic zones. Ecological Engineering 17, 179-186. https://doi.org/10.1016/S0925$\underline{8574(00) 00157-9}$

Bird, P.R. 2000. Farm Forestry in Southern Australia - a focus on clearwood production of specialty timbers. Agriculture Victoria, Pastoral and Veterinary Institute, Hamilton. 264 pp.

Department of the Environment and Energy. 2017. Plantation Forestry Finalised Methodology Determination. Department of the Environment and Energy, Australian Government, Canberra. http://www.environment.gov.au/climate-change/government/emissions-reductionfund/methods/plantation-forestry .

Department of Planning and Environment. 2017. Exploration Code of Practice: Rehabilitation. New South Wales Department of Planning and Environment, Sydney.

Erskine, W. D. and S. Fityus. 1998. Geomorphology of the Hunter Valley, New South Wales and its relevance to natural resource management and development. p. 45-66 In S. Fityus, P. Hitchcock, M. Allman and M. Delaney (Eds). Geotechnical Engineering and Engineering Geology in the Hunter Valley. Australian Geomechanics Society, Newcastle.

Galloway, R. W. 1963. Geomorphology of the Hunter Valley. CSIRO Land Research Series 8: 90-102. 
Kelly, G.L. 2008. Use of soil amendments to maximise wood and carbon values from trees planted on overburden and buffer sites in the Hunter Valley. 82pp. ACARP Final Report C10043.

Lamb, D., P.D. Erskine, and A. Fletcher. 2015. Widening gap between expectations and practice in Australian minesite rehabilitation. Ecological Management \& Restoration 16 186-195. https://doi.org/10.1111/emr.12179

Roberts, J., B. Engel, and J. Chapman. 1991. Geology of the Camberwell, Dungog, and Bulahdelah 1:100,000 sheets 9133, 9233, 9333. 382pp. New South Wales Geological Survey, Sydney.

Singh, G., D. Sier, A. T. Ernst, O. Gavriliouk, R. Oyston, T. Giles and P. Welgama. 2012. A mixed integer programming model for long term capacity expansion planning: A case study from The Hunter Valley Coal Chain. European Journal of Operational Research 220: 210-224. https://doi.org/10.1016/j.ejor.2012.01.012

Walsh, P.G., C.V.M. Barton, and A. Haywood. 2008. Growth and carbon sequestration at age ten years of some eucalypt species in the low- to medium-rainfall areas of New South Wales, Australia. Australian Forestry 71: 70-77. https://doi.org/10.1080/00049158.2008.10676273

Webb, A. A., N. L. Allwood, W. D. Erskine, and S. L. Vernon. 1999. Assessment of riparian revegetation trials on in-channel benches in the Hunter Valley of southeast Australia. Australian Geographical Studies 37: 268-283. https://doi.org/10.1111/1467-8470.00083

Webb, A. A. and W. D. Erskine. 2003. A practical scientific approach to riparian vegetation rehabilitation in Australia. Journal of Environmental Management 68: 329-341. https://doi.org/10.1016/S0301-4797(03)00071-9

Webb, A.A., G.L. Kelly, and N. Cameron. 2017. Sustainable management of plantations for rehabilitation, carbon and wood. 107pp. ACARP Project C20015 Final Report. 